\title{
BELAJAR DEMOKRASI DI SEKOLAH: RE-ORIENTASI PENDIDIKAN DAN PENGEMBANGAN KULTUR SEKOLAH YANG HUMANIS
}

\author{
Suyato \\ Program Studi Pendidikan Kewarganegaraan FIS UNY \\ E-mail: suyato@uny.ac.id
}

\begin{abstract}
This essay explores the factors that cause a lack of effective preparation of citizens supporting the democratic political system carried by educational institutions, especially schools. After describing the global context, in particular the tendency (trend) practices of Citizenship Education that has shifted to the sheer mission preparation productive workforce as it promoted the ideology of neoliberal role strategies educational institutions (schools), not in the setting up of citizens supporting democratic values, further description focuses on the development of the humanist school culture, which the authors believe to be an absolute prerequisite for learning effective democracy. Recently described of learning about democracy effectically, next, it describes theorization of by a description of the importance of critical pedagogy and ended by a description of the change of learning democracy into learning democracy democratically.
\end{abstract}

Keywords: democratic education, school, culture

\section{PENDAHULUAN}

Dalam rentang waktu dekade terakhir perhatian dan sekaligus keprihatinan terhadap pendidikan demokrasi semakin intens baik dari kalangan akademis, pendidik, maupun para politisi. Terkait dengan lembaga pendidikan, perhatian lebih tertuju pada efektivitas peran lembaga pendidikan di dalam upaya penyiapan warga negara melalui proses pendidikan di sekolah. Dengan kata lain kegelisahan berbagai pihak dapat disarikan dalam pertanyaan "Mengapa kita belum menjadi warga negara yang demokratis meskipun upaya untuk itu telah lama dilakukan?”.

Tulisan ini mencoba membahas faktor-faktor penyebab kurang efektifnya penyiapan warga negara pendukung sistem politik demokratis yang disandang oleh lembaga pendidikan, khususnya sekolah. Setelah mendeskripsikan konteks global, khususnya kecenderungan (trend) praktik Pendidikan Kewarganegaraan yang telah bergeser ke semata-mata misi penyiapan tenaga kerja yang produktif sebagaimana yang diusung paham neoliberal tentang peran strategi lembaga pendidikan (sekolah), bukan dalam menyiapkan warga negara pendukung nilainilai demokrasi. Uraian selanjutnya memfokuskan pada pengembangan kultur 
sekolah yang humanis, yang penulis yakini merupakan prasyarat mutlak belajar demokrasi yang efektif. Berikutnya diuraikan tentang teorisasi belajar demokrasi, diikuti oleh uraian tentang pentingnya pedagogi kritis dan diakhiri dengan uraian tentang perubahan dari belajar demokrasi menjadi belajar demokrasi secara demokratis dan penutup

\section{Konteks Global}

Dalam memahami konteks global agenda pendidikan demokrasi, tampaknya menarik untuk menengok kembali tesis Friedman yang menyatakan "the world is flat" di dalam bukunya dengan judul yang sama. Sebagaimana dibahas di dalam buku tersebut, Friedman (2007) menyebutkan setidaknya ada sepuluh "kekuatan" yang membuat dunia semakin "rata", yaitu 1) 11/09/89; 2) 08/09/95; 3) work flow software; 4) uploading; 5) outsourcing; 6) offshoring; 7) supply-chaining; 8) insourcing; 9)in-forming; dan 10) the steroids. Dampak dari kondisi dunia semacam ini adalah adanya kecenderungan global terkait dengan orientasi pendidikan termasuk pendidikan demokrasi melalui PKn, yakni dari upaya penyiapan warga negara yang aktif, kritis, dan peduli terhadap persoalanpersoalan kehidupan berbangsa dan bernegara, menjadi upaya penyiapan calon tenaga kerja yang relevan dan dibutuhkan di dalam dunia kerja dalam masyarakat global yang ditandai oleh dominannya pola pikir sempit, persiapan menjadi tenaga kerja yang siap bersaing secara global.

Deskripsi tentang kecenderungan global tentang pendidikan digambarkan secara berbeda oleh beberapa pakar tetapi senada, misalnya sebagai Educational Genocide (Lucido, 2010); Hegemony under Neoliberalism (Mayo, 2015); Terror of Performativity (Ball, 2006); Teaching by Number (Taubman, 2009) untuk tidak menyebut semuanya. Mereka menyuarakan perlunya menengok kembali hakikat pendidikan agar tidak terlalu jauh keluar dari track.

Dengan mempertimbangkan kondisi sebagaimana diuraikan di muka dan dampaknya bagi dunia pendidikan, maka tidak mengherankan kalau kecenderungan wacana yang berkembang di dalam dunia pendidikan lebih banyak didominasi dengan wacana-wacana ekonomis, seperti kesiapan untuk bersaing secara global (global competitiveness), kepiawaian dan kelincahan (agility), kepatuhan terhadap otoritas atasan (obedience), bukan wacana-wacana yang lazim 
di dalam pendidikan atau pembelajaran demokrasi, seperti kemampuan berpikir kritis (critical thinking), berpikir reflektif (reflective thinking), di samping tentu saja kepatuhan. Efektivitas pembelajaran demokrasi memang bukan hanya ditentukan oleh wacana apa yang dominan tetapi juga kultur dan sarana-prasarana yang kondusif.

\section{Teorisasi Pembelajaran Demokrasi}

Di dalam Concise Oxford English Dictionary, Teaching bisa berarti sebagai berikut:

- To give systematic information to a person, (about a subject or skill).

- To practice this professionally.

- To enable a person to do something by instruction and training (to swim, to dance).

- To be an advocate for a moral principle (my parent taught me forgiveness).

- To communicate, instruct in a moral principle.

- To induce a person by example or punishment to do or not to do a thing (that will teach you to sit still; that will teach you not to laugh).

- $\quad$ To make a person disinclined to do a thing (I will teach you to interfere).

Sedangkan menurut Jarwis (2006, p. 13), seiring dengan perkembangan zaman, guru saat ini tidak lagi: (1) memonopoli dalam hal transmisi pengetahuan; (2) menentukan pengetahuan tetapi mungkin hanya sebagai pemberi makna tentang system pengetahuan yang berbeda; (3) berkaitan dengan kebenaran (truth) meskipun mereka jelas mengajarkannya; (4) mengajar dengan pengetahuan yang tidak berubah meskipun sekarang berhadapan dengan pengetahuan ilmiah ; (5) merasa nyaman di dalam kelas, tetapi seperti orang asing yang memiliki fungsi ketika siswanya membutuhkan; (6) mengajarkan hanya pengetahuan teoretis tetapi sekarang juga membantu para siswa mendapatkan pengetahuan praktis; (7) dapat berasumsi bahwa siswanya tidak memiliki pengetahuan sama sekali tentang materi yang diajarkan tetapi mereka harus belajar untuk membangun pengetahuan yang telah diperoleh siswanya dari beragam sumber.

Perkembangan terkini kecenderungan pembelajaran $\mathrm{PKn}$ mengikuti dominasi paradigma scientific yang sayangnya dimaknai secara sempit sebagaimana yang dianut paradigma positivism dengan ciri penekanan pada halhal yang observable, measurable, standardized, yang tentu saja dengan asumsi satu cocok untuk semua (one size fits all). Pembelajaran demokrasi yang merupakan salah satu elemen penting dari PKn menjadi "kering" dan terjebak 
pada hal-hal yang sifatnya artificial, procedural, bukan essential. Fenomena mengemukanya wacana best practice merupakan salah satu penanda PKn yang sejatinya bersifat political dan contextual ikut terjebak pada logika yang sangat naïf.

\section{Beda Paham, Beda Agenda}

Dalam konteks Pendidikan Kewarganegaraan dan Moral terjadi banyak perdebatan, satu di antaranya adalah perdebatan antara kaum Komunitarian dan kaum Liberal, sebagaimana dirangkum Buxarrais and Esteban (2011, pp. 50-53). Berikut ini disajikan beberapa aspek yang menjadi perdebatan antara paham komunitarian dan liberal terkait dengan PKn dan Moral menurut kedua ahli tersebut. Pertama, berkaitan dengan konsep individu. Menurut Rawlsian liberalism, individu harus dikonsepsikan sebagai sesuatu yang berbeda dari singularitasnya, kualitas personalnya, kondisi sosial spesifiknya, gagasan khusus dia tentang hak dan utamanya, dia harus menggunakan dan mengusahakan konsep-konsep yang berbeda tentang hak. Konsep semacam ini dapat bekerja di dalam konfigurasi komunitas yang setara dan adil, tetapi di mata kaum komunitarian, ini merupakan cara yang salah. Penulis-penulis seperti Michael Sandel (1982) dan Alasdair MacIntyre (1981), berpendapat bahwa pendapat awal dari Rawl mengabaikan bahwa individu terdiri dari tujuan-tujuan moral, nilainilai, dan konsep-konsep tentang hak; bahwa hubungan antara individu dengan tujuan moral adalah esensial, lebih kuat dibanding yang dipikirkan kaum liberal. Jika demikian, memungkinkan insan yang rasional memandang realitas dan sekelilingnya mengabaikan gagasan-gagasan moral dan etis. Dapatkan individu mengubah nilai-nilai semudah yang dibayangkan kaum liberal. Bagi kaum liberal, individu dipandang sebagai orang yang bebas, mandiri, mantap dalam mengambil keputusan tentang langkah hidupnya, sedangkan bagi komunitarian, orang dipandang sesuai dengan nilai-nilai pribadinya, yang merupakan bagian konstituen dari dirinya sendiri dan langkah hidupnya, yang memungkinkan kita untuk bicara tentang seseorang sebagai individu.

Perdebatan kedua, merujuk pada individualisme asosial. Menurut Rawlsian liberalism masyarakat adalah sebuah kemitraan antar individu yang berkumpul secara privat, yang kepentingan pribadinya ditetapkan tanpa 
memandang komunitas di mana mereka berada. Dengan kata lain, individu terindividualisasikan mendahului pilihannya tentang tujuan, identitasnya telah terbentuk sebelumnya, oleh karena itu, akan selalu ada jarak antara siapa dia dengan nilai-nilai yang dianutnya. Dalam istilah Kantian kita bisa bicara bahwa apa yang membuat kita menjadi manusia bukanlah tujuan kita, kepentingan kita, gagasan-gagasan pribadi kita, tetapi kemampuan kita untuk berpikir dan bertindak dengan kemandirian, yang hanya merupakan penggerak bagi pilihan pribadi dan privat kita. Bagi para penulis Komunitarian, khususnya Alasdair MacIntyre (1981) dan Charles Taylor (1990), liberalisme mengabaikan peran komunitas di dalam menyebarkan identitas dan nilai-nilai mereka. Jika boleh dikatakan, orang merupakan parasit bagi komunitasnya, karena konsep pribadi tentang diri seseorang berasal dari komunitas. Bagi liberalisme masyarakat adalah sebuah kerja sama individu-individu, sementara komunitas lebih dari itu. Masalah ini menjadi krusial di dalam pendidikan moral dan kewarganegaraan, dan ini menggarisbawahi kritik sosiologis terhadap individualisme postmodern.

Masalah ketiga, berkaitan dengan universalisme. Teori Rawlsian memiliki pendekatan universal. Fakta bahwa filsafat diusahakan untuk mencari kebenaran memaksanya untuk membedakannya dari kondisi lingkungan sekitarnya. Bagi liberalisme, semua komunitas yang rasional dapat mempraktikkan prinsip-prinsip keadilan sebagai kesetaraan, tetapi dari perspektif komunitarian pandangan ini mengabaikan kekhasan moral dan budaya, kenyataan bahwa kelompok budaya yang berbeda juga memiliki cara pandang yang berbeda dalam memahami dasardasar nilai dan etika. Komunitarian menyalahkan liberalisme karena mengabaikan kondisi spesifik yang memungkinkan terjadinya pemahaman relatif atau relativisme.

Perdebatan keempat, terkait dengan subjectivism dan objectism. Menurut Teori Rawlsian Liberalism, dari uraian di muka bisa disimpulkan bahwa pilihan akan tujuan, nilai-nilai, dan konsep tentang hak adalah preferensi subjektif. Sedangkan menurut kaum komunitarian memandang manusia adalah makhluk bermoral dengan basis masyarakat atau komunitasnya. Tegasnya, sumber moral berasal dari tradisi masyarakat. 
Perdebatan terakhir, berkaitan dengan anti-perfectionism dan neutrality. Kaum Liberal meletakkan harapan pada negara dan lembaganya, termasuk lembaga pendidikannya tetap dalam kondisi netral (tidak memihak kepada salah satu pihak). Dengan kata lain, otoritas penguasa tidak memaksakan pada satu logika moral tertentu dan menghalangi lainnya. Menurut Kaum komunitarian, ada nilai-nilai tertentu yang lebih baik disbanding dengan lainnya. Kalau negara tidak mengusahakan atau melindungi nilai-nilai tersebut maka ada risiko akan lenyap.

Pattie, et.al. (2004, p. 275) membuat perbedaan antara choice-based theories of citizenship yang melihat kewarganegaraan muncul dari pilihan yang dibuat para pelaku individu, dan structural-based theories of citizenship yang melihat kewarganegaraan lebih sebagai outcomes dari norma-norma, nilai-nilai dan perilaku kelompok di mana individu bergabung dan masyarakat di mana individu hidup. Lebih lanjut para pakar ini membagi choice-based theories of citizenship menjadi dua, yaitu 1) cognitive engagement theory, berasumsi bahwa partisipasi bergantung pada akses individu terhadap informasi, kemampuan dan kemauan mereka untuk menggunakan informasi itu untuk membuat pilihan tertimbang; dan 2) general incentives theory yang memfokuskan lebih banyak pada insentif yang mendorong individu untuk berpartisipasi dan terlibat. Sedangkan structural-based theories of citizenship oleh mereka dibagi menjadi tiga: 1) civic voluntarism model, melihat partisipasi warga negara sebagai outcomes dari interaksi beragam sumber daya (waktu, uang, dan keterampilan kewarganegaraan), sikap kewarganegaraan seperti efikasi politik dan keterlibatan politik, dan perasaan akan tanggung jawab untuk berpartisipasi; 2) the equityfairness theory yang memfokuskan penjelasan tentang partisipasi politik dan kewarganegaraan utamanya disebabkan karena perasaan dan 3) the sosial capital model

Terkait dengan agenda kependidikan menghadapi era economic-based society, tampaknya relevan untuk mempertimbangkan diskusi yang dilakukan Aspin and Chapman sebagaimana dikutip Biesta (2011, p. 63) tentang lifelong learning agenda yang menurut mereka setidaknya memiliki tiga agenda yang berbeda, yaitu: 1) belajar sepanjang hayat bertujuan untuk pembangunan dan kemajuan ekonomi (economic progress and development); 2) belajar sepanjang 
hayat untuk perkembangan dan pemenuhan pribadi (personal development and fulfillment); dan 3) belajar sepanjang hayat yang memiliki agenda untuk inklusifitas sosial dan aktivitas dan pemahaman demokratis (sosial inclusiveness and democratic understanding and activity.

De Groot (2011, pp. 85-90) menyebutkan ada lima dimensi aspek sikap positif terhadap demokrasi dan keberagaman yang meliputi: 1). elaborate understanding of democracy and diversity, mencakup: reflection on own values, positioning, and personal diversity dan sensitivity to sosial justice issues; 2).capacity, mencakup internal and external efficacy; 3).active relations, mencakup commitment and connection; 4). willingness to transform; 5). dialog, mencakup: empathy and dialogical competencies.

\section{Pengembangan Budaya Sekolah Yang Humanis}

Pembelajaran demokrasi melalui mata pelajaran Pendidikan Kewarganegaraan saja tidak cukup. Agenda ini membutuhkan dukungan dari berbagai pihak, satu diantaranya berupa budaya sekolah yang kondusif. Budaya sekolah yang kondusif bagi bersemainya sikap dan perilaku demokratis antara lain ditandai dengan kultur atau budaya sekolah yang humanis. Oleh karena itu, agenda mendesak terkait dengan re-orientasi pendidikan dalam rangka penguatan nilai-nilai demokrasi di sekolah salah satunya adalah pengembangan kultur sekolah yang humanis.

Terkait dengan upaya pengembangan kultur sekolah yang humanis, Aloni (2011, pp. 41-45) mengemukakan tujuh aspek krusial sebagai berikut: 1) multifaceted cultivation of student personality; 2) developing a sosial climate of security and fairness; 3) empowering dialogues; 4) a communitarian approach and sosial involvement; 5) general education and cultural foundations; 6) the tree knowledge as a tree of life; 7) a safe, aesthetic and hospitable physical infrastructure. Uraian singkat ketujuh aspek tersebut dapat dikemukakan sebagai berikut.

1. Pengembangan kepribadian siswa yang beragam. Prinsip keberagaman dalam pengembangan kepribadian siswa memiliki akar sejarah sejak zaman Athena sampai sekarang dengan konsep kecerdasan ganda (multiple intelligences). Berkaitan dengan aspek pertama ini, Aloni menyebutkan tujuh aspek atau ciri 
penting, yang meliputi: a). membantu siswa untuk mengembangkan citra positif atau perasaan berharga seperti berharga, penting, diterima dan mampu sebagai prasyarat keyakinan akan kemampuan mereka untuk mengarahkan kehidupannya secara berkualitas dan bermakna; b). memajukan minat mereka terhadap lingkungan manusia dan alam dalam rangka menumbuh-kembangkan kenyamanan hidup dan keterlibatan di dalam aktivitas sosial dan materi budaya; c). mengembangkan kecerdasan emosional mereka dan kapasitas untuk berempati, moderasi, dan kematangan diri (self-mastery); d). mengembangkan nilai-nilai intelektual seperti rasa ingin tahu, berpikir kritis dan reflektif, keputusan yang logis, imajinasi kreatif, dan sensitivitas terhadap nilai; e). memajukan sudut pandang pemikiran yang mandiri, akuntabilitas pribadi dan ketangguhan di dalam menangani masalah-masalah intelektual, tekanan sosial dan harapan serta tuntutan pribadi; f). menumbuh-kembangkan suara pribadi yang otentik yang menghasilkan isi dan membentuk sendiri melalui dialog antarpribadi akan pengasuhan dan motivasi diri sendiri; g). dan mengembangkan dorongan untuk menjadi "tidak sempurna" dan bertindak dalam situasi yang ambigu dan mengambil solusi sederhana (Aloni, 2011, p. 42).

2. Iklim sosial akan keamanan dan keadilan. Mengutip pernyataan psikolog Amerika Serikat Abraham Maslow, kondisi sosial anak ibarat kondisi akuarium ikan mas: karena, baik kondisi utama dan dasar akan keamanan dan kenyamanan adalah esensial untuk survival meskipun ringan. Kondisi yang optimal bisa mencegah atau minimal mengurangi agresi dan kebencian anak dan segala hal yang berkaitan dengan masalah disiplin yang bisa menghambat kesuksesan akademik anak. Khususnya, berikut ini merupakan kondisi yang penting: (a) sebuah perasaan akan keamanan secara mental, emosional, dan fisik, yang ditransformasikan menjadi kondisi nyaman dan rileks; (b) sebuah atmosfer keluarga yang peduli dan empati, bersama-sama dengan perhatian pribadi oleh para guru dan sebuah perasaan bahwa siswa hormat terhadap mereka secara pribadi; (c) sebuah perasaan turut memiliki dan kemitraan diperkuat dengan keterlibatan secara aktif di dalam pengambilan keputusan berkaitan dengan kultur sekolah; (d) norma-norma akan alasan, kejujuran, 
dialog, dan transparansi dengan menekan sedikit mungkin pemaksaan dan sikap otoriter; dan (e) norma-norma akan saling menghormati dan peduli termasuk keadilan sosial dan lingkungan (Aloni, 2011, p. 42).

3. Dialog yang memberdayakan. Maksudnya adalah cara yang khas akan wacana pedagogis dan komunikasi antar pribadi yang memperkaya pembelajaran rutin dengan unsur-unsur dan isi yang memperkuat dan memberdayakan kepribadian siswa melampaui materi yang dipelajari. Lebih lanjut Aloni menyatakan beberapa tipologi sebagai berikut. (a) dialog Socratis yang secara intelektual memberdayakan; (b) dialog Nietschean yang memberdayakan kemandirian dan autentisitas dengan menolak pilihan akan konformitas masa dan mendorong alternatif pembentukan diri pribadi siswa berdasarkan definisi diri dan kreasi diri sendiri; (c) dialog Buberian yang mengembangkan sensitivitas kepedulian dan empathy di dalam interaksi yang ditandai dengan kehadiran kepribadian dari kedua belah pihak, baik dari guru maupun siswa; (d) dialog Rogersian yang mengembangkan keyakinan individu akan kemampuan dirinya yang mengantarkan kesuksesan dengan mengenali dan mencocokkan dirinya sendiri; (e) dialog Freireian yang membantu siswa dari kelompok sosial yang lemah dan tertindas untuk membebaskan diri mereka sendiri dari kekuasaan yang menindas dengan cara mengembangkan pengetahuan aktif dan melek secara kritis dan penerapannya di dalam perjuangan politik untuk mendapatkan keadilan sosial dan kesempatan yang setara; dan (f) dialog ekologis yang menguatkan kepedulian terhadap lingkungan alam (ekologis).

4. Pendekatan komunitas dan keterlibatan sosial. Dimensi ini mencakup; (1) keterlibatan yang lebih besar dari siswa dan orang tua baik dalam pengembangan materi pelajaran maupun kegiatan ekstra kurikuler serta peraturan tata tertib sekolah; (2) sistem pendukung bagi kelompok yang tercerabut dari akar budaya dan tidak beruntung secara ekonomis, termasuk kondisi fisik dan mental; (3) kolaborasi dengan organisasi sosial di dalam komunitas seperti kelompok, gerakan anak muda, taman kanak-kanak, organisasi penyayang binatang, dan lain-lain; kewarganegaraan aktif yang 
bertujuan menghapus ketidakadilan sosial dan menjamin integritas dan kemakmuran baik untuk kepentingan publik dan lingkungan alamiah.

5. Pendidikan umum dan landasan budaya. Dimensi ini mencakup: (1) melek literasi, termasuk keterampilan ekspresi dan komprehensif, kemampuan untuk menganalisis teks yang rumit, penyajian gagasan yang tertata dan rasional, dan kemampuan untuk mendiskusikan beragam isu; (2) pendidikan umum, termasuk pandangan dunia dan warisan budaya, konsep dasar dan metode penelitian, seni dan isu kontemporer; (3) pengetahuan tentang mata pelajaran; (4) keterampilan kognitif yang ditunjukkan dengan kemampuan berpikir kritis rasional dan reflektif, kreatif, dan kemampuan untuk memutuskan fakta dan nilai; (5) pendekatan filosofis yang memajukan kepedulian akan kebenaran dan keadilan, tidak menerima begitu saja dan memperjelas dan metode berpikir dan ekspresi; dan (6) literasi estetis, menikmati seni dan bekerja dengan estetika dan keterampilan artistic.

6. Pohon pengetahuan sebagai pohon kehidupan. Dimensi ini mencakup: (1) mengganti kurikulum berbasis mata pelajaran dengan program pengembangan kependidikan sebagai dasar isi; (2) pembelajaran yang bermakna sejalan dengan dunia nyata siswa dan masalah kontemporer; (3) menciptakan pedagogi yang menunjukkan antusiasme untuk keyakinan, keadilan, dan keindahan; (4) menerjemahkan pengetahuan menjasi literasi kehidupan yang memungkinkan siswa mengidentifikasi pesan-pesan yang sarat nilai terkait isu-isu yang didiskusikan di ruang kelas dan merencanakan tindakan dengan penuh alasan dan tanggung jawab; (5) pendekatan holistic yang mendasarkan pada kecerdasan ganda dan interpersonal; dan (6) pendekatan asesmen yang beragam terkait dengan kemampuan, fungsi, dan kontribusi siswa.

7. Infrastruktur fisik yang nyaman, aman, dan indah. Lansekap fisik sekolah yang memfasilitasi pencapaian prestasi individu dan tujuan budaya, yang mencakup; (1) gedung, media pelajaran, dan taman yang aman; (2) arsitektur yang nyaman dan estetis; (3) akses yang terbuka dan banyak ruang untuk belajar mandiri, interaksi sosial, dan dialog kelompok kecil. 


\section{Pentingnya Pedagogi Kritis}

Pedagogi kritis memberikan kesempatan dan berupaya mengembangkan kesadaran pentingnya memiliki kontrol terhadap kehidupan sosial mereka sendiri melalui proses pendidikan. Menurut bahasa Dewey dan Freire, siswa perlu dilatih praktik-praktik transformatif (transformative practices). Enam hal yang didaftar Giroux (1983, p. 202), yang meliputi partisipasi aktif, berpikir kritis, pengembangan autobiografi pribadi, pelacakan nilai-nilai yang terikat di dalam eksistensi manusia, belajar tentang kekuatan ideologis dan structural yang menghambat kesempatan untuk berkembang, dan menunjukkan bagaimana untuk membuat struktur politik secara bersama-sama yang menantang status quo.

Sementara itu, Preece and Griffin (2006, p. 53) lebih suka menggunakan istilah pedagogi radikal (radical pedagogy), yang mereka artikan sebagai a theory of practice that specifically aims to empower oppressed groups or challenge traditional forms of sosial and political oppression. Lebih lanjut mereka menyatakan bahwa karena kondisi terus berubah maka mereka yang termasuk ke dalam kelompok ini tidak lagi mendasarkan analisis mereka pada sosialisme, marxisme atau feminism, tetapi di dalam kompleksitas dan ambiguitas kondisi postmodern. Singkatnya, kata mereka, apa yang dimaksud dengan pedagogi kritis tidak lagi hanya memfokuskan pada aspek politik saja tetapi mencakup kesadaran kritis atau refleksifitas, inklusi sosial dan kewarganegaraan, termasuk hegemoni dan kekuatan budaya (Preece and Griffin, 2006, p. 53).

Stephen Brookfield, sebagaimana dikutip Jarwis, Holford, and Griffin (2004, p. 69) mengemukakan empat komponen berpikir kritis, yaitu (1) mengenali dan mempertanyakan asumsi-asumsi; (2) mempertanyakan pentingnya konteks; (3) bersedia mencari alternatif; dan (4) bersikap skeptic secara reflektif. Bagi dia, bersikap kritis tidak berarti tidak setuju, tetapi ada kemauan untuk bertanya, bukan semata-mata menerima situasi dan informasi. Dia menyamakan dengan pengertian berpikir reflektif, sehingga berpikir tidak kritis sama dengan berpikir secara tidak reflektif.

Dalam bidang PKn, termasuk pendidikan moral di dalamnya, Veugelers (2011, pp. 20-21) mengidentifikasi beberapa isu yang relevan dengan praktik pedagogis yang ditujukan untuk menciptakan warga negara demokratis yang 
kritis. Isu itu antara lain meliputi: 1) tata cara seperti komunikasi nilai, di mana para siswa belajar untuk berpikir dan bertindak dengan mempertimbangkan nilainilai. Pertimbangan nilai tentu saja membutuhkan kriteria untuk menelaah perilaku, seperti nilai keadilan (Power, Higgins \& Kohlberg, 1989); 2) nilai-nilai yang mendorong perilaku, komponen afektif dari perkembangan moral perlu mendapatkan perhatian. Kepedulian, keterlibatan dan partisipasi adalah komponen penting dari domain sosial; 3) untuk menemukan dimana nilai-nilai moral itu penting, perkembangan sensitivitas moral, dan kemampuan untuk mengelola emosi itu penting (Tirri, 2008); dan 4) beberapa pendekatan pendidikan moral terkini di dalam bidang kependidikan ditandai dengan pendekatan terintegrasi untuk pencapaian keterampilan komunikasi nilai, stimulasi nilai tertentu-yang sering diorientasikan untuk kewarganegaraan demokratis kritis, dan perhatian terhadap sekolah sebagai komunitas (Solomon, Watson \& Battistisch, 2001; Veugelers \& Oser, 2003).

\section{Dari Belajar tentang Demokrasi ke Belajar Demokrasi secara Demokratis}

Belajar demokrasi harus dimaknai bukan merupakan proses yang linier, artinya merupakan proses yang menyangkut aspek-aspek pengalaman positif maupun negatif, sehingga bersifat fluktuatif. Belajar demokrasi dan kewarganegaraan juga bukan semata-mata hasil dari pengalaman di sekolah tetapi juga yang diperoleh dalam konteks kehidupan sehari-hari, baik di lingkungan keluarga, masyarakat, tempat kerja dan lain-lain. Meskipun bukan merupakan proses yang bersifat linier, belajar demokrasi bersifat cumulative, karena berbagai pengalaman masa lalu, baik yang positif maupun negatif terbawa terus ketika belajar sesuatu yang baru dengan sifat fluktuasinya. Belajar demokrasi juga bersifat recursive karena melibatkan proses me-recall pengalaman masa lalu. Dengan kata lain, belajar demokrasi melibatkan proses reflektif.

Terkait dengan pembahasan ini, perlu dipertanyakan adanya kesenjangan antara apa yang diharapkan dengan kenyataan di lapangan, misalnya: Mengapa sesorang belum juga bersifat demokratis, sementara ia telah lama "belajar" demokrasi, atau tegasnya: mengapa sikap demokratis belum juga tertanam sedangkan mereka telah cukup lama belajar demokrasi. Jawaban atas pertanyaan ini, antara lain dijelaskan Groot (2011, pp. 85-90) yang menyatakan ada lima 
prasyarat untuk tumbuh kembangnya sikap demokratis, yaitu (1) elaborasi pemahaman tentang demokrasi dan keberagaman, yang mencakup refleksi atas nilai-nilai yang dianutnya, positioning (penempatan diri), dan keberagaman secara personal serta sensitivitas terhadap isu-isu keadilan sosial; (2) kapasitas seseorang untuk berpartisipasi dengan secara demokratis yang tercerahkan, yang mencakup perasaan bahwa yang bersangkutan memiliki self-efficacy, baik secara internal maupun eksternal; (3) menjalin relasi aktif, yang mencakup koneksi dan komitmen; (4) kemauan untuk melakukan transformasi; dan (5) kemauan dan kemauan untuk melakukan dialog, yang mencakup empathy dan kemampuan dialogis.

\section{KESIMPULAN}

Berdasarkan uraian di muka dapat ditarik kesimpulan bahwa belajar demokrasi sangat tergantung pada kondisi kontekstual, baik global, nasional, maupun lokal (kultur sekolah dan kelas). Konteks global yang didominasi agenda neoliberalisasi berdampak pada bergesernya misi PKn dari upaya penyiapan warga negara yang well-informed, committed, dan active sebagaimana yang dikehendaki sistem politik demokrasi ke upaya penyiapan tenaga kerja yang productive, agile, smart, dan governable sesuai dengan tuntutan dunia kerja yang bersifat global. Pada konteks lokal, penciptaan kultur sekolah yang kondusif merupakan prasyarat untuk belajar demokrasi secara efektif. Dimensi individu yang memengaruhi efektivitas belajar demokrasi mencakup pemahaman demokrasi dan keberagaman, kapasitas memposisikan diri, menjalin relasi, kemauan melakukan transformasi, dan kemampuan melakukan dialog. Singkatnya, seorang guru PKn perlu memperhatikan aspek-aspek determinan mulai dari global, nasional, lokal, sekolah, kelas sampai karakteristik personal peserta didik.

\section{DAFTAR PUSTAKA}

Aloni, N., 2011.’Humanistic Education: From Theory To Practice”, In Wiel Veugelers, (Ed.). Education And Humanism, Linking Autonomy And Humanity. Rotterdam/Boston/Taipei: Sense Publishers.

Ball, S.J., 2006. Education Policy And Sosial Class, The Selected Works Of Stephen J. Ball. London: Routledge. 
Biesta, Gert.J.J. 2011. Learning Democracy In School And Society, Education, Lifelong Learning, And The Politics of Citizenship. Rotterdam/Boston/Taipei: Sense Publishers.

Buxarrais, M.R., and Esteban, F., 2011. "Moral Education From A Humanist Perspective" In Wiel Veugelers, (Ed.). Education And Humanism, Linking Autonomy And Humanity. Rotterdam/Boston/Taipei: Sense Publishers.

Friedman, T.L., 2007. The World Is Flat. New York: Picador.

Groot, Isolde De., 2011.,"Why We Are Not Democratic Yet: The Complexity Of Developing A Democratic Attitude", in Wiel Veugelers, (Ed.). education and humanism, linking autonomy and humanity. Rotterdam/Boston/Taipei: Sense Publishers.

Jarwis, P., 2006. “Teaching In A Changing World” In Jarwis, P. (Ed.). The Theory And Practice Of Teaching $2^{\text {nd }} E d$. London And New York: Routledge.

Jarwis, P., Holford, J., and Griffin, C. 2004. The Theory And Practice Of Learning $2^{\text {nd }} E d$. London And Sterling: Kogan Page.

Lucido, H. 2010. Educational Genocide. New York: Rowman\&Littlefield Publishers.

Mayo, P. 2015. Hegemony And Education Under Neoliberalism, Insights From Gramsci. New York: Routledge.

Pattie, C., Seyd, P., and Whiteley, P. 2004. Citizenship In Britain: Values, Participation And Democracy. Cambridge: Cambridge University Press.

Power, F.C., Higgins, A., and Kohlberg, L. 1989. Lawrence Kohlberg's approach to moral education. New York: Columbia University Press.

Solomon, D., Watson, M.S., \& Battistich, V.A. 2001. Teaching And Schooling Effects On Moral/Prososial Development. In V. Richardson (Ed)., Handbook Of Research On Teaching (566-603). Washington: AERA.

Taubman, P.M. 2009. Teaching By Numbers Deconstructing The Discourse Of Standards And Accountability In Education. New York And London: Routledge.

Tirri, K. 2008. Moral Sensibilities In Urban Education. Rotterdam/Taipeh/Boston: Sense Publishers.

Veugelers, W.,(Ed.). 2011. Education And Humanism, Linking Autonomy And Humanity. Rotterdam/Boston/Taipei: Sense Publishers.

Veugelers, W. 2011, "A Humanist Perspective On Moral Development And Citizenship Education" In Wiel Veugelers, (Ed.). Education And Humanism, Linking Autonomy And Humanity. Rotterdam/Boston/Taipei: Sense Publishers. 